\title{
Bearded seal (Erignathus barbatus) vocalizations across seasons and habitat types in Svalbard, Norway
}

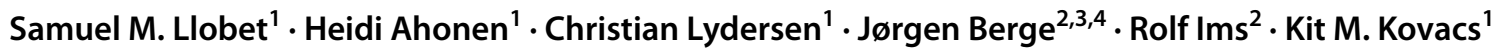

Received: 5 March 2020 / Revised: 25 March 2021 / Accepted: 20 April 2021 / Published online: 17 May 2021

(c) The Author(s) 2021

\begin{abstract}
Male bearded seals (Erignathus barbatus) use vocal displays to attract females and to compete with other males during the mating season. This makes it possible to monitor breeding populations of this species using passive acoustic monitoring (PAM). This study analysed year-round acoustic data records from AURAL instruments in Svalbard (Norway) to investigate seasonal variation in the acoustic presence of male bearded seals and the phenology of different call types (long, step and sweep trills) at three sites representing a variety of habitats with varied ice conditions. Male bearded seals vocalized for an extended period at a drift-ice site (Atwain; January-July) north of Spitsbergen, while the vocal season was shorter at a High Arctic land-fast-ice site (Rijpfjorden; February-June) and shorter yet again at a west-coast site that has undergone dramatic reductions in sea ice cover over the last 1.5 decades (Kongsfjorden; April-June). Generalized Additive Models showed marked seasonal segregation in the use of different trill types at Atwain, where call rates reached 400 per h, with long trills being the most numerous call type. Modest segregation of trill types was seen at Rijpfjorden, where call rates reached 300 per $\mathrm{h}$, and no segregation occurred in Kongsfjorden (peak call rate 80 per h). Sea ice cover was available throughout the vocal season at Atwain and Rijpfjorden, while at Kongsfjorden peak vocal activity (May-June) occurred after the sea ice disappeared. Ongoing climate warming and sea ice reductions will likely increase the incidence of such mismatches and reduce breeding habitat for bearded seals.
\end{abstract}

Keywords Arctic $\cdot$ Breeding $\cdot$ Climate change $\cdot$ Mating period $\cdot$ Passive acoustic monitoring $\cdot$ Sea ice

\section{Introduction}

Bearded seals (Erignathus barbatus) have a circumpolar distribution across the Arctic, preferentially occupying areas where there is drifting sea ice over shallow shelf waters (Burns 1981; Kovacs 2018). They are primarily benthic foragers, though they have been reported to feed on a variety of pelagic organisms as well in some parts of their range (e.g. Hjelset et al. 1999). Bearded seals tend to choose areas with polynyas, or places where the occurrence of flaw leads is

Kit M. Kovacs

kit.kovacs@npolar.no

Norwegian Polar Institute, 9296 Troms $\varnothing$, Norway

2 UiT The Arctic University of Norway, Troms $\varnothing$, Norway

3 University Centre in Svalbard, Longyearbyen, Norway

4 Centre for Autonomous Marine Operations and Systems, Department of Biology, Norwegian University of Science and Technology, Trondheim, Norway recurrent over years, avoiding areas with very heavy concentrations of ice (Kovacs 2018). In some parts of their range, bearded seals maintain a close association with drifting sea ice year-round, while in other areas they use pieces of ice that have broken away from land-fast-ice or even ice pieces that have calved from glacier fronts for both resting and rearing their young (e.g. Lydersen et al. 2014; Cameron et al. 2018). During spring, female bearded seals give birth on ice floes; the precise timing of pupping is somewhat variable across the range of the species (between mid-March and early-May; e.g. Burns 1981; Kovacs et al. 1996). Mothers nurse their pups for approximately 24 days (Kovacs et al. 1996, 2020; Lydersen and Kovacs 1999). During the lactation period, female bearded seals continue to forage, with their pups accompanying them after they are a few weeks old (Lydersen et al. 1994; Krafft et al. 2000). Mating takes place in the water, towards the end of the lactation period, similar to many other phocid seals (Burns 1981; Lydersen and Kovacs 1999). 
During the breeding season, adult male bearded seals produce elaborate underwater vocalizations (e.g. Cleator et al. 1989; Van Parijs et al. 2001). There is considerable geographic variation in the vocal repertoire among populations in Alaska, the Western Canadian Arctic, the Canadian High Arctic and Svalbard (Risch et al. 2007). Differences in vocal phenology also exist. For example, bearded seals vocalize year-round in the Beaufort Sea (MacIntyre et al. 2013), whereas they vocalize in a more seasonally restricted fashion in Svalbard, with most calling taking place in the period from February to July (Van Parijs et al. 2001; Parisi et al. 2017). Some call types, such as moans, a short duration vocalization of low to mid-frequency, seem to be widely used outside the mating season, but use of these shorter calls decreases towards the peak of the mating period (FrouinMouy et al. 2016; Parisi et al. 2017). Trills are the dominant call type during the months that mating occurs (Van Parijs et al. 2001; Risch et al. 2007; Frouin-Mouy et al. 2016; Parisi et al. 2017). Trills are long duration calls that exhibit frequency modulation and occur across a wide frequency band; they are assumed to advertise the breeding condition of males (Burns 1981; Cleator et al. 1989). The repeated (redundant) use of such loud, highly stereotyped, downward sweeps in frequency reduces masking of these calls by competing males and background noise, presumably increasing the opportunities of attracting mates (Cleator et al. 1989; Terhune 1999; Rogers 2003; Stirling and Thomas 2003). Trills have been used as a proxy to estimate the duration of the mating season both in Svalbard and in the north-eastern Chukchi Sea (Van Parijs et al. 2001; Frouin-Mouy et al. 2016). Through the study of trill vocalizations, Van Parijs et al. $(2001,2003,2004)$ demonstrated that individual male bearded seals used different breeding strategies and that mating tactics were strongly influenced by sea ice conditions. Some males maintained underwater territories with little overlap under variable ice conditions, returning to the same location year after year (territorial males), while other "roaming" males patrolled larger areas and did not vocalize when ice was extensive (>60\%; Van Parijs et al. 2003). The territorial tactic was dominant in Svalbard (Van Parijs et al. 2003), where territorial males produced significantly longer duration trills than males that displayed a roaming strategy. However, in Alaska, territorial males produced shorter trill vocalizations than roaming males and the latter strategy was the dominant tactic in this area, where ice conditions are quite unstable (Van Parijs and Clark 2006). It has been hypothesized that differences in ice conditions likely drive the different mating tactics and different use of calls in the various Arctic regions.

Reduction in the geographic and seasonal extent of sea ice in the Arctic is a concern for all ice-breeding seals including bearded seals (Kovacs and Lydersen 2008; Moore and Huntington 2008; Kovacs et al. 2011). Less sea ice will likely result in higher energy expenditure, poorer body condition and reduced recruitment (Moore and Huntington 2008; Kovacs et al. 2011; MacIntyre et al. 2013), but the lack of baseline data on bearded seal abundance and trends in population sizes will make it challenging to detect demographic impacts of climate change on this species (Laidre et al. 2015). However, acoustic studies can be used to increase our knowledge regarding distribution, habitat use, phenology and relative abundance of vocal marine mammal species, as well as facilitating an increased understanding of the relationship of different species with environmental variables and anthropogenic activities (e.g. Moore et al. 2012; Stafford et al. 2012; Reeves et al. 2014; Ahonen et al. 2019). Previous studies of the acoustic behaviour of Svalbard's bearded seals have all been conducted in Kongsfjorden (Fig. 1a, b) (Van Parijs et al. 2001, 2003, 2004; Parisi et al. 2017; de Vincenzi et al. 2019). These research efforts have contributed to a better understanding of the vocal biology of this species and provide a baseline for future monitoring efforts. However, comparative studies involving additional locations within the archipelago are likely to be insightful regarding how bearded seals might be responding to climate change on a broader regional scale. In this study, bearded seal vocalizations were explored from acoustic data collected at three Passive Acoustic Monitoring (PAM) sites around Svalbard Archipelago: (1) Kongsfjorden on the west-coast of Spitsbergen, where Atlantification of this previously Arctic fjord is quite advanced and little land-fast-ice forms in winter, (2) a north-east coastal site in Rijpfjorden, which retains an Arctic environment with a lot of shore-fast spring ice and (3) Atwain, a drift-ice site north of the archipelago. The latter two sites have not been studied previously with respect to bearded seal ecology. The use of different call types and the phenology of vocal behaviour during the breeding season was studied in depth with the aim of describing how bearded seals reproductive ecology is being impacted by reduced sea ice availability in mid-west Svalbard compared to northeastern parts of the archipelago, which are less impacted to date by warming (e.g. Urbanski and Litwicka 2021; Weydmann-Zwolicka et al. 2021).

\section{Material and methods}

\section{Study area and acoustic data collection}

Three Autonomous Underwater Recorders for Acoustic Listening (AURAL M2, Multi-Électronique Inc.; receiving sensitivity of $-164 \pm 1 \mathrm{~dB}$ re $1 \mathrm{~V} / \mu \mathrm{Pa}$ and a signal saturation level of $155 \mathrm{~dB}$ re $1 \mu \mathrm{Pa}$ when system gain is set to $16 \mathrm{~dB}$ ) were deployed on stationary oceanographic moorings in order to collect year-round underwater acoustic data (Fig. 1). These locations in Kongsfjorden, Rijpfjorden and 


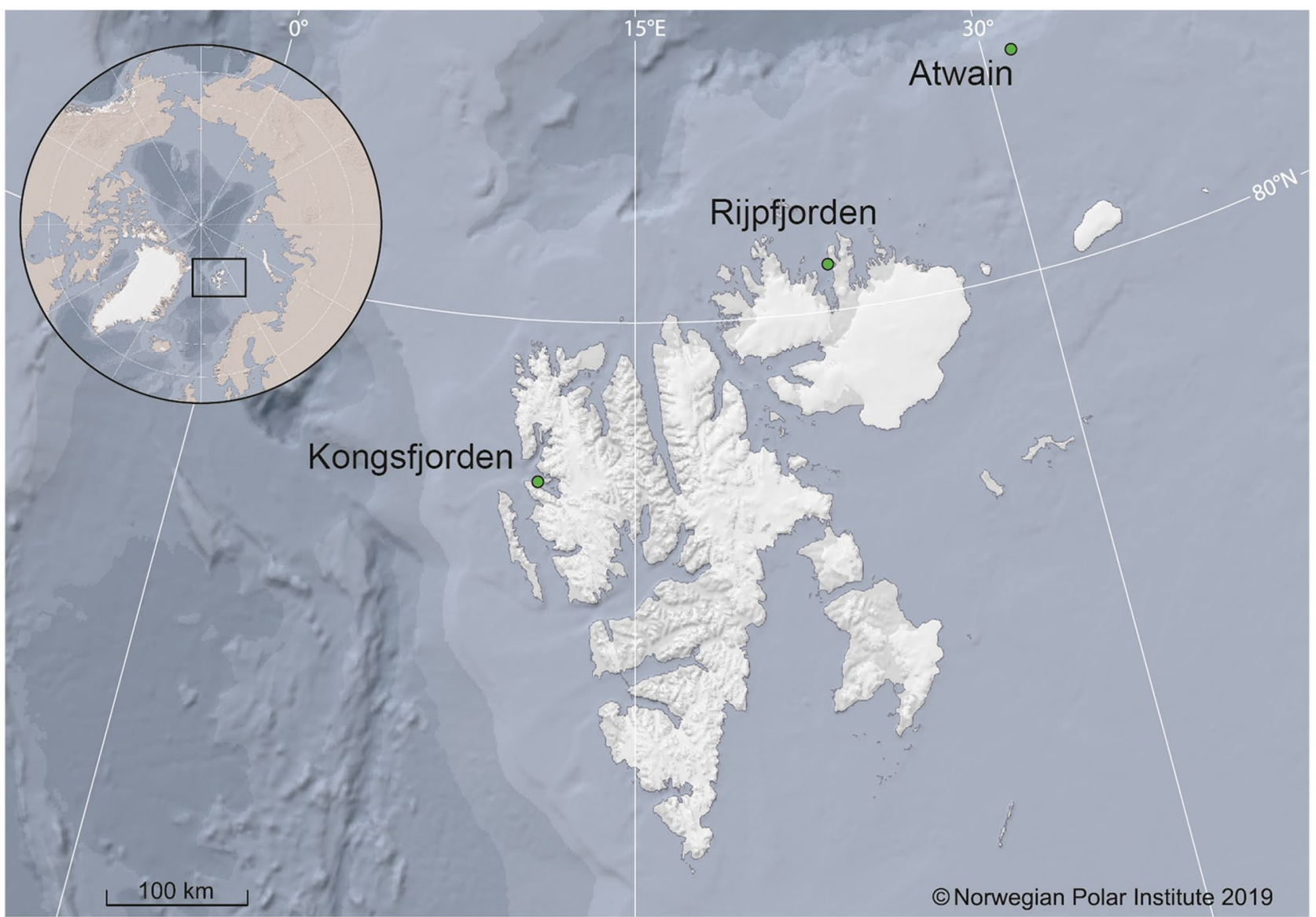

b

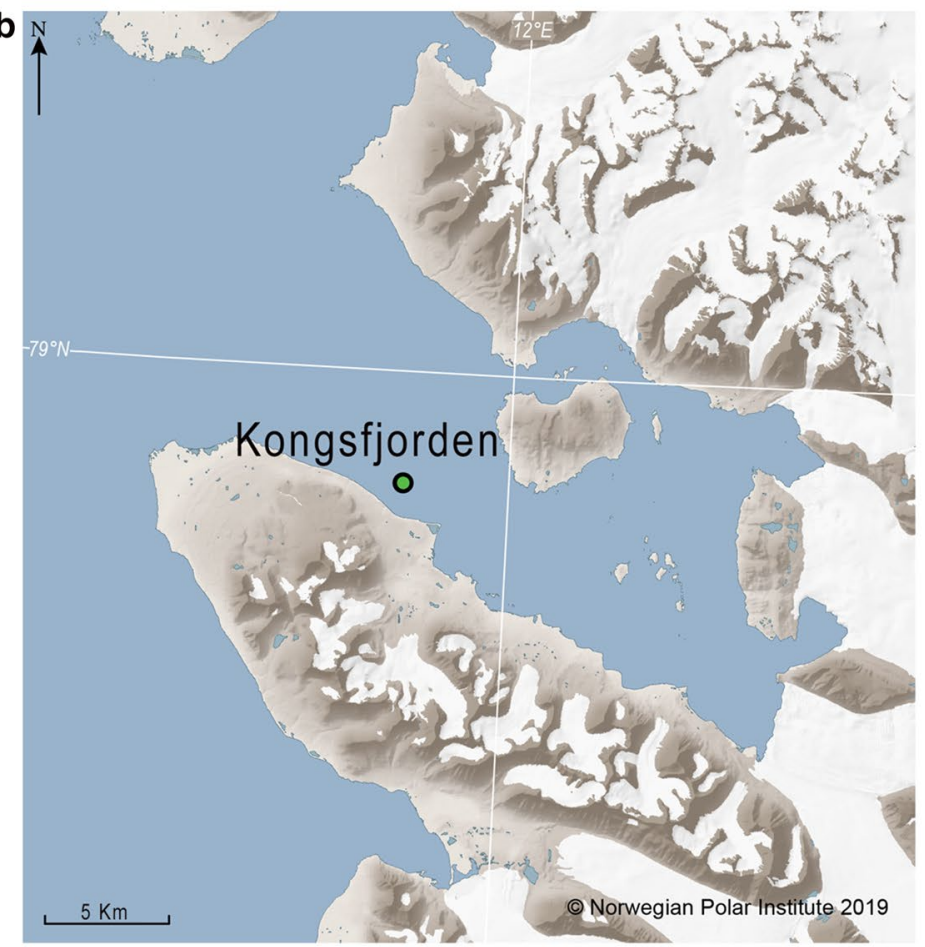

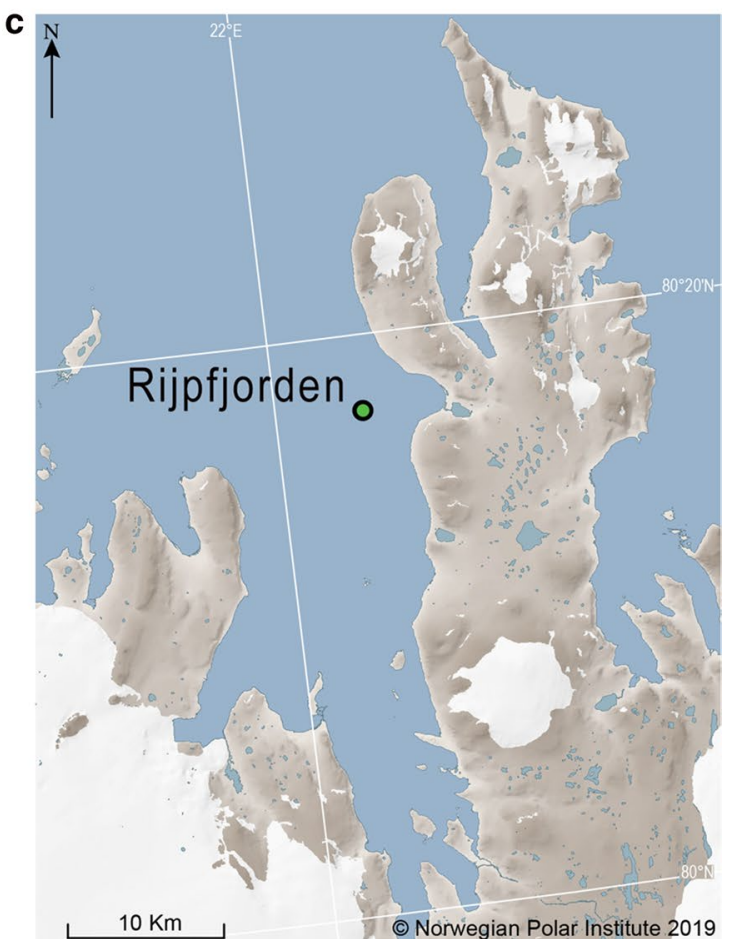

Fig. 1 Study area and locations (green dots) of the three AURAL recorders (a), with more detailed scales for the mooring sites in fjords—b Kongsfjorden and $\mathbf{c}$ Rijpfjorden 
at Atwain represent a gradient of environmental conditions (Cottier et al. 2007; Wassman et al. 2015; Renner et al. 2018). Kongsfjorden was a high-density breeding site for bearded seals prior to the sea ice collapse of 2006, but this area has undergone extensive reductions in sea ice in recent years due to increased incursions of warm Atlantic Water (carried along the coast in the West Spitsbergen Current), which come up onto the shelf following strong north-easterly winds (Cottier et al. 2007; Blanchet et al. 2015; Tverberg et al. 2019). Rijpfjorden is much less influenced by Atlantic Water and thus remains a more typical Arctic fjord (Wallace et al. 2010). The Atwain mooring is situated at the edge of the continental shelf north of the Svalbard Archipelago; ice in the vicinity of this station is drift-ice. This mooring is part of an instrumentation platform that provides data for the A-TWAIN project (https://www.npolar.no/en/projects/atwain/), whose aim is to study Atlantic Water inflow to the Arctic Ocean north of Svalbard.

The data collection period in this study extended from September 2014 to August 2016, including one year of data from each location. In Kongsfjorden, data were recorded from 25 September 2014 to 15 August 2015 with a 25\% duty cycle (the 15 first minutes of every hour). In Rijpfjorden, data were recorded from 20 September 2015 until 26 August of 2016, with a $20 \%$ duty cycle (the 12 first minutes of every hour). At Atwain, the recording period started 20 September 2015 and extended until 31 August 2016. This recorder had a 20\% duty cycle, similar to Rijpfjorden, recording the first 12 min of every hour. The sampling rate for all instruments was $32,768 \mathrm{~Hz}$. Full deployment details for each location are presented in Table 1.

\section{Acoustic data and bearded seal call detections}

Spectrograms of each acoustic file (one file for each hour) were generated using the bioacoustics software Ishmael (version 3.0) in order to screen the data records for bearded seal vocalizations (10-6000 Hz, FFT 20,148/4096, 75\% overlap, Hanning window). This study follows the most recent classification of the underwater vocal repertoire of bearded seals in Svalbard, which recognizes nine different vocalization types (Parisi et al. 2017). Firstly, bearded seal vocal presence was assessed by scoring every hour in a binary manner for the entire recording period at each location; detections of any of the nine vocalization types were assigned a (1) and an absence of calling was assigned a (0). Subsequently, three selected trill vocalizations-long trill, step trill and sweep trill (Fig. 2)--were counted in each file to study breeding activity in detail, as these vocalizations have been associated with the mating period in other studies (Van Parijs et al. 2001; Risch et al. 2007; Parisi et al. 2017). These specific vocalizations were counted from 1 February to 31 July (weeks 1 to 26), in an attempt to include the whole potential breeding period in the different environments. The three trill types and their sum (trills), which reflects overall trill activity, were used to visualize and compare vocal activity among the three study sites.

\section{Data analysis}

\section{Seasonality of trill types and overall trill activity: comparison across locations}

In order to explore whether overall trill rates differed between locations, as well as to test whether some trill types were more or less abundant in the different locations, Generalized Additive Models (GAMs) were run for the overall trill activity ("trills") and for each trill type ("long", "step", "sweep") using the package "mgcv 1.8-28" (Wood 2016) in R (version 3.6.0; R Core Team 2019). The variables "trills", "long", "step" and "sweep" were used as the input response variables for each of the models. The predictor variable "week" was included as a thin-plate spline smooth term and "location" was included as a "by" factor variable in each smooth term. Because the sampling rate was $12 \mathrm{~min}$ per h for Rijpfjorden and Atwain, and 15 min per h for Kongsfjorden, an offset term with the variable "time" was introduced into the models, which accounted for the difference in sampling rates when predicting vocal rates. The distribution family chosen for the models was Tweedie (Tweedie 1984) because it has a flexible distribution that can be used for many different types of count data; it is often used with zero-inflated count data (Wood et al. 2016). Tweedie uses a P parameter, which behaves like a Poisson distribution if the $\mathrm{P}$ parameter equals one, or it can adopt a Gamma distribution when $\mathrm{P}$ equals two. When using Tweedie in GAMs, the best fitting parameter $\mathrm{P}$ is automatically estimated by the model. After running the models, the function "predict.gam" (R package
Table 1 Deployment details for each location in Svalbard, 2014-2016

\begin{tabular}{lllll}
\hline Location & Coordinates & Recording dates & $\begin{array}{l}\text { Water/Recorder } \\
\text { depth }(\mathrm{m})\end{array}$ & $\begin{array}{l}\text { Duty } \\
\text { cycle } \\
(\mathrm{min})\end{array}$ \\
\hline Kongsfjorden & $78.960 \mathrm{~N} 11.800 \mathrm{E}$ & $25 / 09 / 14-15 / 08 / 15$ & $223 / 50$ & 15 \\
Rijpfjorden & $80.290 \mathrm{~N} 22.300 \mathrm{E}$ & $20 / 09 / 15-26 / 08 / 16$ & $236 / 55$ & 12 \\
Atwain & $81.400 \mathrm{~N} 31.230 \mathrm{E}$ & $20 / 09 / 15-31 / 08 / 16$ & $200 / 57$ & 12 \\
\hline
\end{tabular}




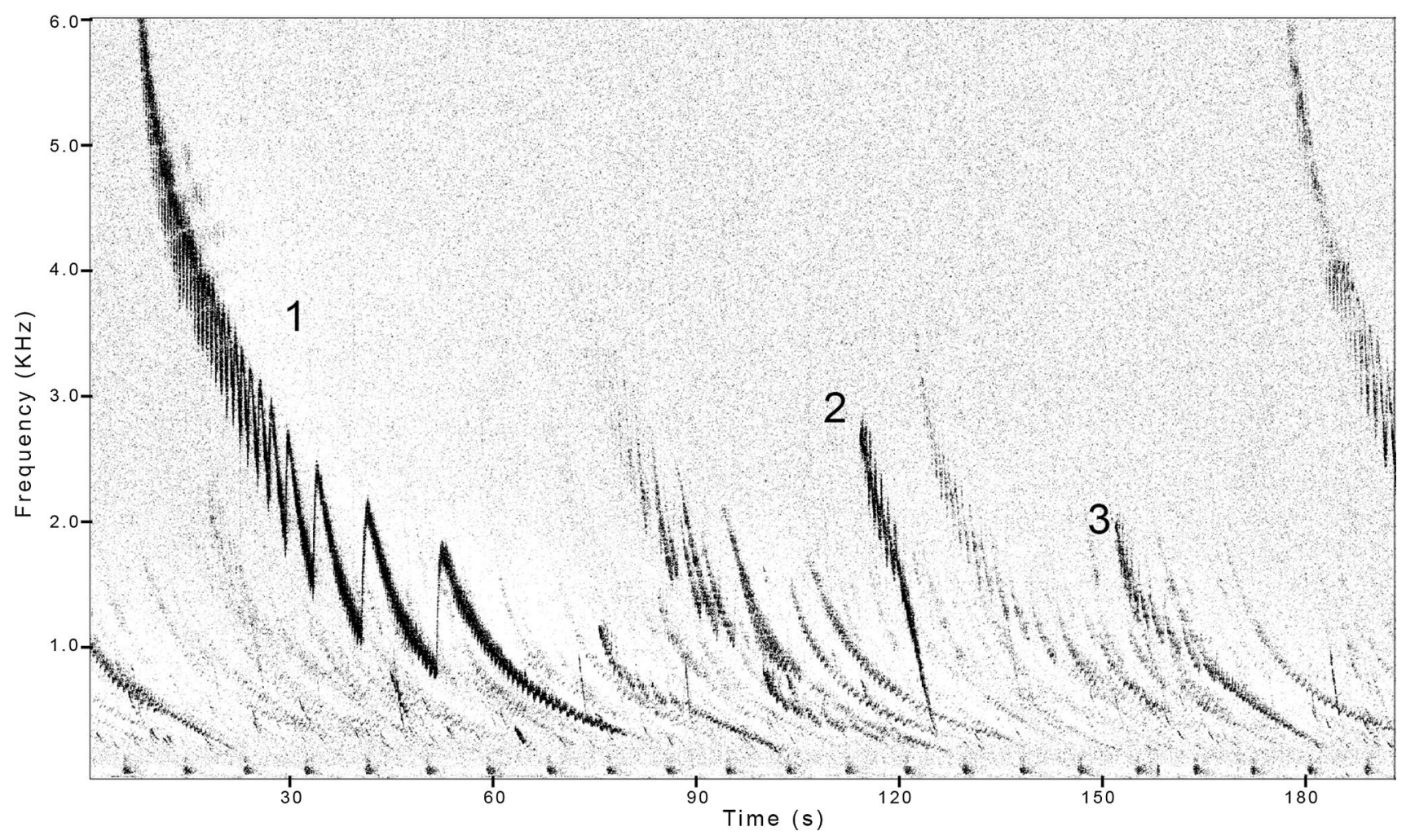

Fig. 2 Spectrogram (FFT size 8192 points; Hann Window) of bearded seal (Erignathus barbatus) vocalizations at Atwain. (1) A long trill, (2) a sweep trill and (3) a step trill. Frequency and time are indicated on $y$-and $x$-axes, respectively

"mgcv 1.8.28, Wood et al. 2016) was used to predict the overall trill rates and to predict and compare the rates of the three different trill call types at the various locations. For model validation purposes, the residuals versus the fitted values were plotted for identification of outliers and compared to those of other error distributions than those automatically selected (e.g. Poisson distribution, negative binomial distribution).

\section{Seasonality and segregation of trill types and overall trill activity by site}

To test whether there was differential use of the three trill call types through the mating season (within locations), a GAM model with the response variable "trills" (number of trill calls per day) and the predictor variables "week" and "type" (the later corresponding to trill call type: "long", "step", "sweep") was run for each location. The variable "week" was once again included as a smooth term (thinplate spline) with "type" included as a "by" variable within the smooth term, so that a separate smooth term was made for each call type. The distribution family selected for this model was again Tweedie. After running the models, the function "predict.gam" was used to predict and compare the vocalization rates of the three different trill calls and the overall trill rates by location. Model validation was conducted as described above.

\section{Ice cover data}

Sea ice data were obtained from the Norwegian Meteorological Institute (https://cryo.met.no) and used to calculate daily ice cover for each study site (spatial resolution of $\sim 50 \mathrm{~m}$ ). Most bearded seal vocalizations are detected within a radius of $5 \mathrm{~km}$ from a recorder, though in very calm, quiet conditions up to $15 \%$ of calls can be detected from as far away as $20 \mathrm{~km}$ (Cleator et al. 1989; MacIntyre et al. 2013). To study possible influences of ice cover in the area where bearded seal vocalizations occurred, 1000 points were randomly generated (Gaussian distribution) within a radius of $20 \mathrm{~km}$ from the recorder at each location. Land points (Kongsfjorden, Rijpfjorden) were eliminated, as well as points falling in adjacent fjords or those outside line-of-sight of a recorder. The rest of the points were used to extract the ice cover information from a shapefile for each date over the data collection period (function "over" from R package "sp 1.3-1"; Bivand et al. 2013). If ice cover information was not available for a given day, the closest day was selected as being representative. Ice cover was expressed as the proportion of the area covered by different ice concentration percentages 
( $>10 \%,>40 \%,>70 \%,>90 \%$, Fast-Ice). Plots of ice cover and trill vocalizations per day were generated to visualize and compare the sea ice cover and the trill activity in the period February to July.

\section{Results}

\section{Annual vocal presence}

A total of $5260 \mathrm{~h}$ of acoustic records were screened for bearded seal vocalizations at the three study sites. In Kongsfjorden, vocal presence of bearded seals was detected initially towards the end of April (2015; Fig. 3a). A pronounced increase in the hours of vocal presence per day occurred in the following weeks. A constant vocal presence, with calls occurring $24 \mathrm{~h}$ per day, was documented from about mid-May until mid-June (one month), after which the hours with calling dropped suddenly. No bearded seal signals were detected after the end of June in Kongsfjorden. In Rijpfjorden, vocal presence was first detected in early-February (2016; Fig. 3b). By the end of March, bearded seal vocal presence was constant ( $24 \mathrm{~h}$ per day) and remained so until the end of June (three months), when it suddenly decreased to zero. At the northernmost recorder (Atwain), vocal presence was detected from the beginning of January (2016; Fig. 3c). The number of hours per day with vocal presence of bearded seals increased progressively towards the end of February. Constant vocalizations started around the end of March and lasted until mid-July (4 months) when the number of hours per day with vocal presence suddenly decreased to zero. Overall, Kongsfjorden had the shortest period with vocal presence of bearded seals ( 2 months), followed by Rijpfjorden ( 5 months) and Atwain (almost 7 months).

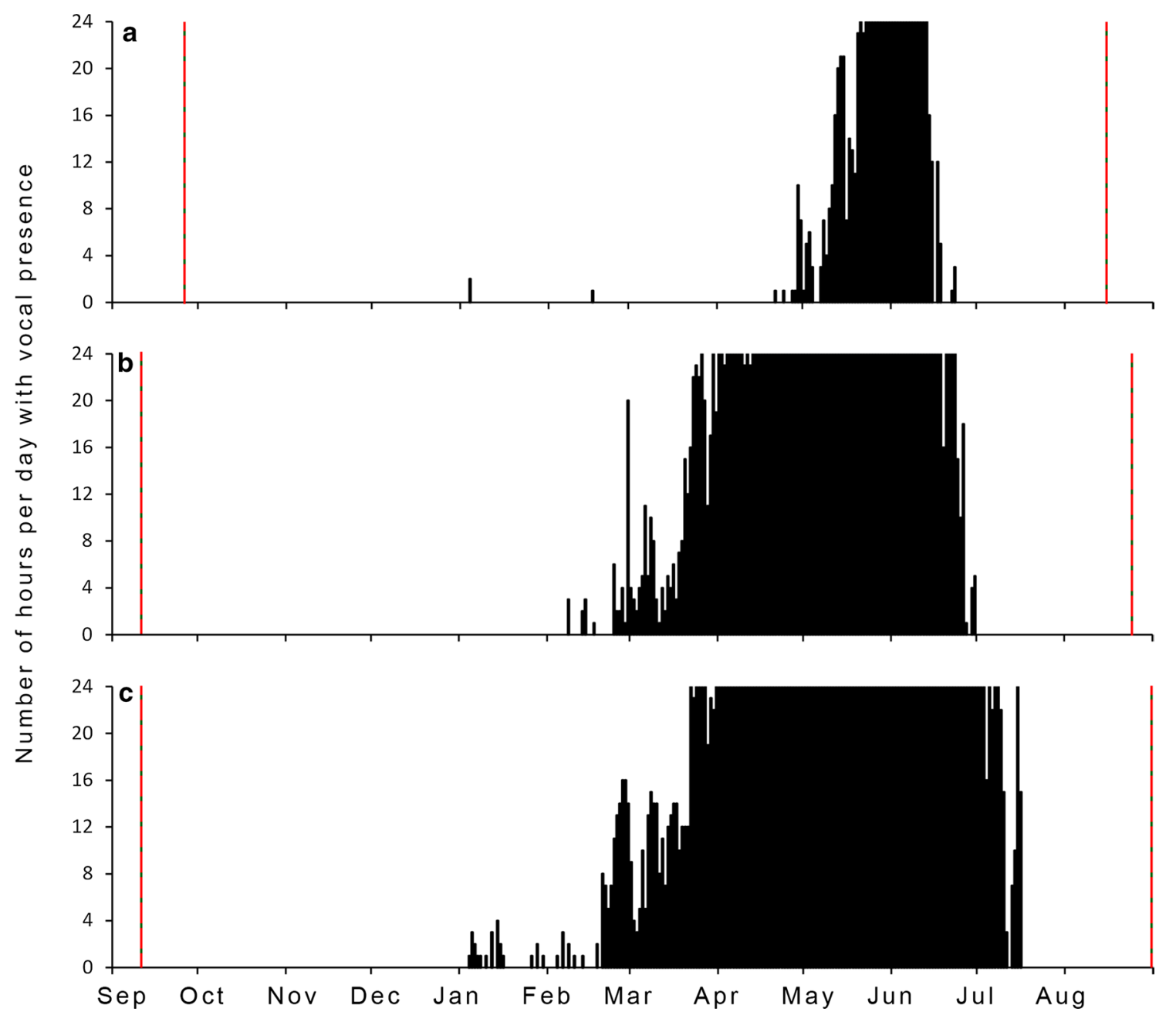

Fig. 3 Seasonal acoustic detections of bearded seal (Erignathus barbatus) vocalizations in a Kongsfjorden, b Rijpfjorden and $\mathbf{c}$ Atwain. The vertical black lines show the number of hours per day with acoustic detections, while the vertical red lines show the start and end of the recording period at each location 


\section{Seasonal variation in trill rates and use of trill types}

Kongsfjorden had the lowest call rates in terms of overall trill vocalizations per $\mathrm{h}$ in the period from February to July (Fig. 4a). Trills were performed from week 12 to week 21, with peak calling occurring in week 18 (first week of June). Rijpfjorden had much higher trill rates than Kongsfjorden and a much longer season during which trills were produced (Fig. 4b). At this site, trill vocalizations were performed from week 7 to week 21 (mid-March to late-June). A sharp increase in trill rates occurred during April, followed by a progressive decline during May and June. A peak in trill rates (in excess of 300 trills per h) occurred in weeks 13 and 14 (end of April until early-May). Atwain had the longest season with trills, with these calls being produced from week 8 through until week 24 (Fig. 4c). This site also had the highest trill rates with more than 300 trills per $\mathrm{h}$ for an extended period from late-April through until June. Trills continued to be detected at Atwain regularly until July, after which they declined sharply. Overall, Kongsfjorden had lower trill rates than Rijpfjorden or Atwain (Fig. 5a). Trill rates were similar between Rijpfjorden and Atwain during April, when they increased sharply at both locations. From May onwards, trill rates started to decrease at Rijpfjorden, but continued to increase at Atwain, being significantly higher in this latter location. Higher trill rates at Atwain were observed for all trill types (Fig. 5b, 5c), except for the sweep trill. Significantly higher rates of sweep trill were observed during April in Rijpfjorden compared to Atwain (Fig. 5d). A bimodal distribution of the trill vocal phenology was seen at Atwain, with the first peak in late-April and a second peak in early-June; single peaks occurred at the other two sites (Fig. 5a). The relative use of the three different types of trills varied monthly at Atwain and Rijpfjorden, while there were no significant differences in trill type usage in Kongsfjorden (Fig. 6a). However, Rijpfjorden showed only minor differences in median call rates among the trill types by month compared to Atwain where there were clear temporal differences in use of the different trill types (Fig. 6b, c). Most notably, long trills were used significantly more at Atwain than the other trill types, particularly in May.

\section{Vocalizations and sea ice cover}

Kongsfjorden had the least ice cover among the three study sites and trill vocalizations at this site started when the ice cover had almost completely disappeared (Fig. 7a). In Rijpfjorden, trill vocalizations were concentrated in a period when ice cover was 70 to $90 \%$ (Fig. 7b). Sporadic increases in calling after the April peak matched temporary increases

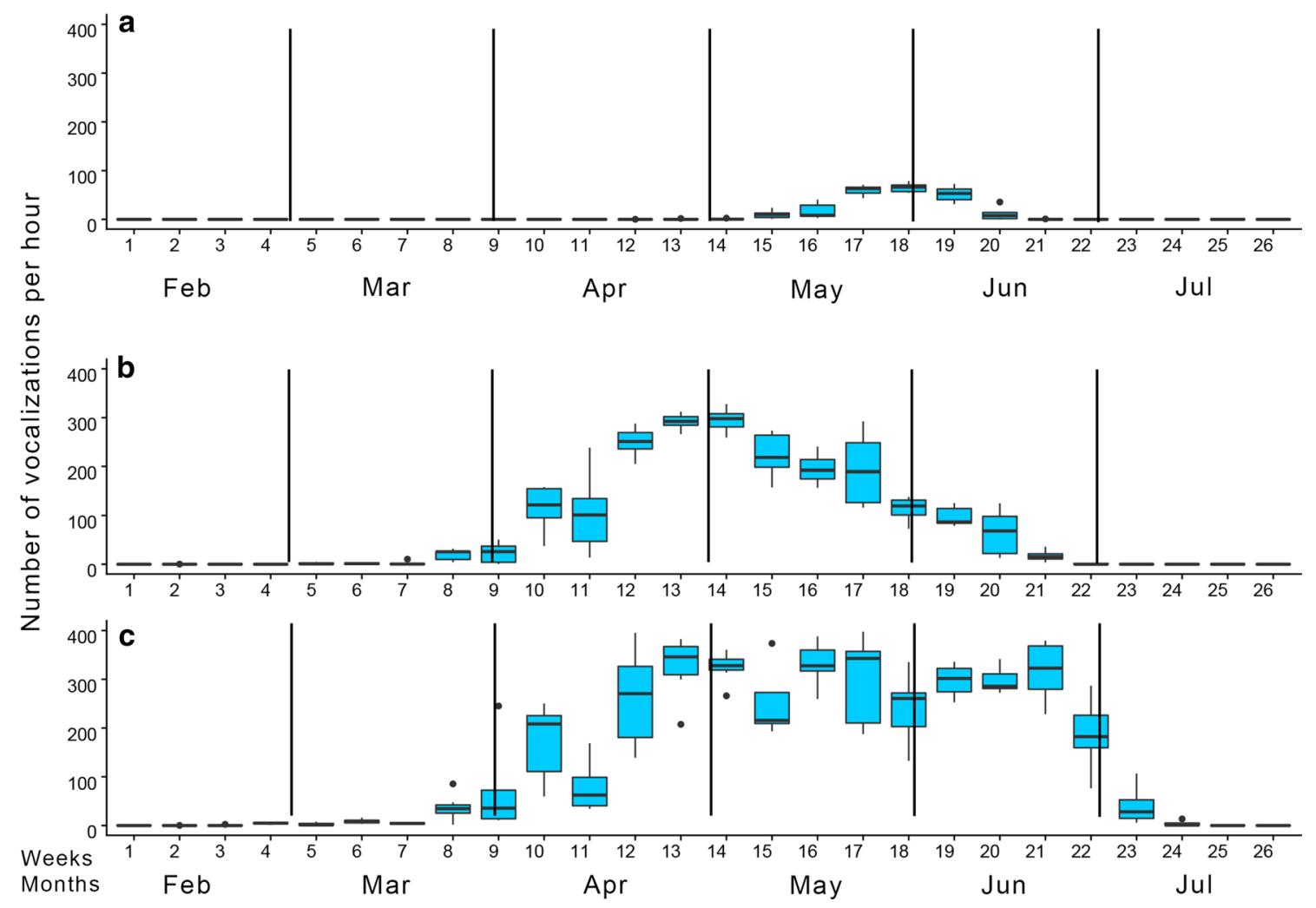

Fig. 4 Median hourly number of trill vocalizations per week (February to July) in a Kongsfjorden, b Rijpfjorden and c Atwain. Blue boxes show 25-75th percentiles, while the vertical lines indicate 1st-99th percentiles 


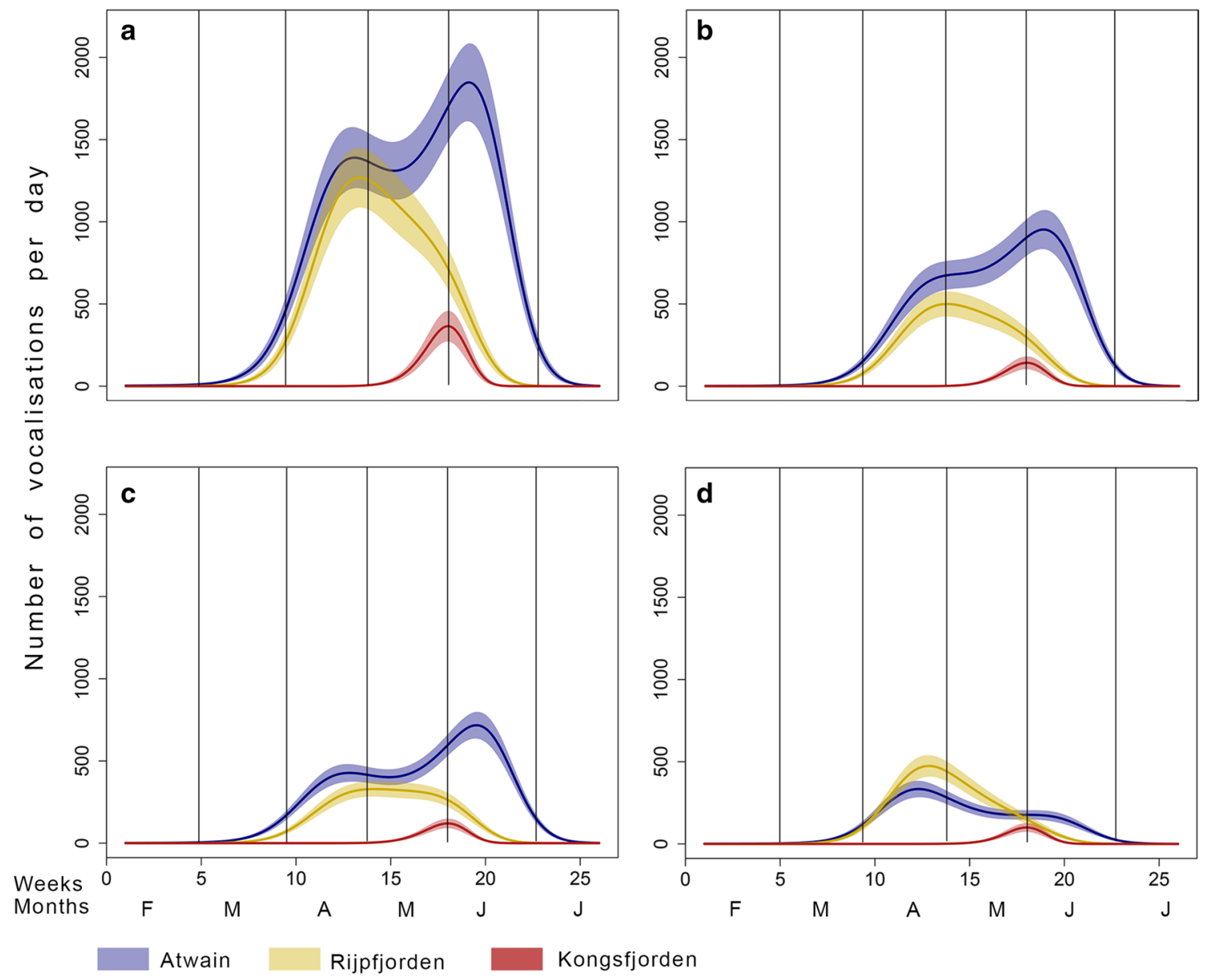

Fig. 5 Results of Generalized Additive Models predicting the daily rate of vocalizations for each location, in different colours. $\mathbf{a}=$ overall trills, $\mathbf{b}=$ long trill, $\mathbf{c}=$ step trill and $\mathbf{d}=$ sweep trill. The $y$-axis indicates the number of vocalizations per day while the $x$-axis shows the

in ice cover (May and June). The peak in trill rates was coincident with the start of the fast-ice break-up in early-May. A decrease in trill rates was concomitant with the overall reduction of the ice cover at this site. Ice conditions at Atwain were extremely variable, but at least $10 \%$ ice cover was present throughout the season when the bearded seals performed trill calls (Fig. 7c). The first peak in trill activity coincided with ice cover over $70 \%$ and some reductions in trill counts were seen when there was a period with very high sea ice concentrations ( $>90 \%)$.

\section{Discussion}

This study provided year-round acoustic information on bearded seal vocalizations from three locations within the Svalbard Archipelago, where earlier acoustics studies of this species in this region had only taken place in Kongsfjorden date in weeks. The vertical bars in the plots show divisions between months February to July, indicated by capital letters (F-J) on the $x$-axis. The solid lines indicate mean values and the shadowed areas reflect $\pm 95 \%$ CI

(Van Parijs et al. 2001, 2003, 2004; Parisi et al. 2017; de Vincenzi et al. 2019). The current study included sites with quite different habitat characteristic, including (1) Kongsfjorden, which has undergone significant Atlantification over the past 1.5 decades, (2) Rijpfjorden, which is a more typical Arctic fjord, and (3) an open water drift-ice location (Atwain). The latter two sites have not been studied with passive acoustics previously. The drift-ice site, Atwain, is the northernmost location where bearded seal vocalizations have been monitored globally.

Bearded seals were vocally present at all three study sites in Svalbard. Their calling behaviour was species-typical, but there were marked differences in the period over which calls were detected as well as in the intensity (rate) of calling among the different sites/habitat types. The Atwain driftice site had the longest seasonal presence of bearded seals vocalizations, with detections from January until mid-July and a $24 \mathrm{~h}$ vocal presence from the end of March until 

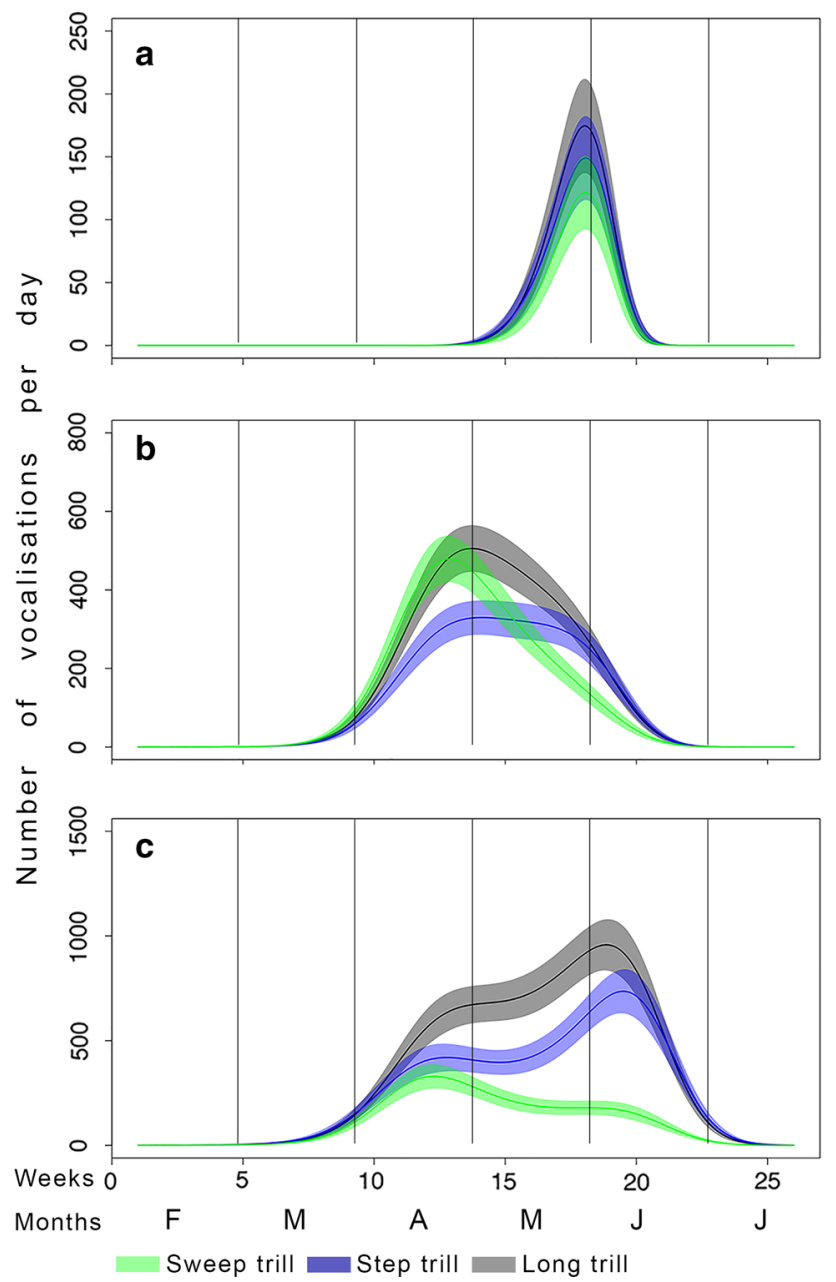

Fig. 6 Results of generalized additive models predicting the daily rate of vocalizations for each trill call type for a Kongsfjorden, b Rijpfjorden and $\mathbf{c}$ Atwain. The $y$-axis indicates the number of vocalizations per day while the $x$-axis shows date in weeks. The vertical bars in the plots show divisions between months February to July, indicated by capital letters $(\mathrm{F}-\mathrm{J})$ on the $x$-axis.

The solid line indicate mean values and the shadowed areas reflect $\pm 95 \%$ CI

mid-July. This finding was surprising given that drift-ice had previously not been thought to be an important bearded seal habitat in the Barents Region. It has been assumed that most bearded seal breeding took place in shallow shelf areas near the coast (e.g. Kovacs et al. 2020). However, drift-ice environments of the Chukchi and Beaufort seas in Alaska are known to be key bearded seal habitats (MacIntyre et al. 2015; Jimbo et al. 2019). In Rijpfjorden, bearded seals had a vocal presence from February until June, and a $24 \mathrm{~h}$ presence from March until the end of June. This is typical for several other locations across the bearded seals' range, with a modestly extended period of male singing, around the peak period when most mating is assumed to take place (e.g. Cleator et al. 1989). In contrast, Kongsfjorden had the shortest period of bearded seal vocal presence among the three locations; at this site bearded seals were detected only from late-April until late-June, with a $24 \mathrm{~h}$ vocal presence lasting approximately half of that period, from mid-May until mid-June. de Vincenzi et al. (2019) reported data from two recorders from the same year in Kongsfjorden as the current study. Their outermost recorder reported vocal presence by bearded seals only in May and June. The second recorder, which detected vocalizations from bearded seals from February until early-June, was close to the Kronebreen glacier front in the inner part of Kongsfjorden. The variable seasonal detections by site within the same fjord highlights the importance of local knowledge of the regional ecology of species when placing PAM recorders. Key habitats must be targeted, and these may shift through time, particularly given the rapid warming currently taking place in the Arctic.

Vocalizations emitted by male bearded seals during the mating period are mainly long duration trills of various types that shift downward in frequency through the call (e.g. Cleator et al. 1989; Van Parijs et al. 2001). The long durations of such calls and perhaps their main frequencies are thought to provide information to females and to other males regarding their size, social rank, fitness level or other traits of the singers (Owings and Morton 1998; Van Parijs et al. 2003; Taylor and Reby 2010; Charlton and Reby 2016). Although simple assessments of peak vocal activity can provide information on the likely timing of the mating period and the distribution of males (Cleator et al. 1989; Van Parijs et al. 2001), finer scale information, such as trill rates and types, are better suited to study the relation between overall vocal activity, mating tactics and environmental factors (Van Parijs et al. 2003, 2004; Van Parijs and Clark 2006). Trill rates are thought to be a reasonably good reflection of the number of males vocalizing in an area because individuals have been shown to maintain quite constant calling rates throughout the breeding season (Van Parijs et al. 2001), especially when rates differ as greatly between areas as was observed in the current study.

Vocal rates were the highest at Atwain in this study, with a sustained period containing trill calls occurring from April until late-June, in which almost 400 trills per h were recorded during the peak weeks of the season. These results resemble those reported for the drift-ice environment of the north-eastern Chukchi Sea by Frouin-Mouy et al. (2016). The rates are somewhat lower at Atwain compared to the Pacific site, but more call types were included in the study by Frouin-Mouy et al. (2016) than the three trill types that were the focus of the current study. These earlier authors also reported a high degree of inter-annual variability in call rates. This is not unexpected, given that drift-ice environments are extremely variable from year to year. The situation at Atwain is likely similar, though multiyear analyses will be required to confirm this suggestion. It is possible that 
Fig. 7 Daily vocal rates of bearded seals (Erignathus barbatus) in relation to the sea ice cover from February to July in a Kongsfjorden, b Rijpfjorden and $\mathbf{c}$ Atwain. Daily trill counts are shown on the $y$-axis on the left, while the proportion of the area covered by a given ice class is displayed in the $y$-axis to the right

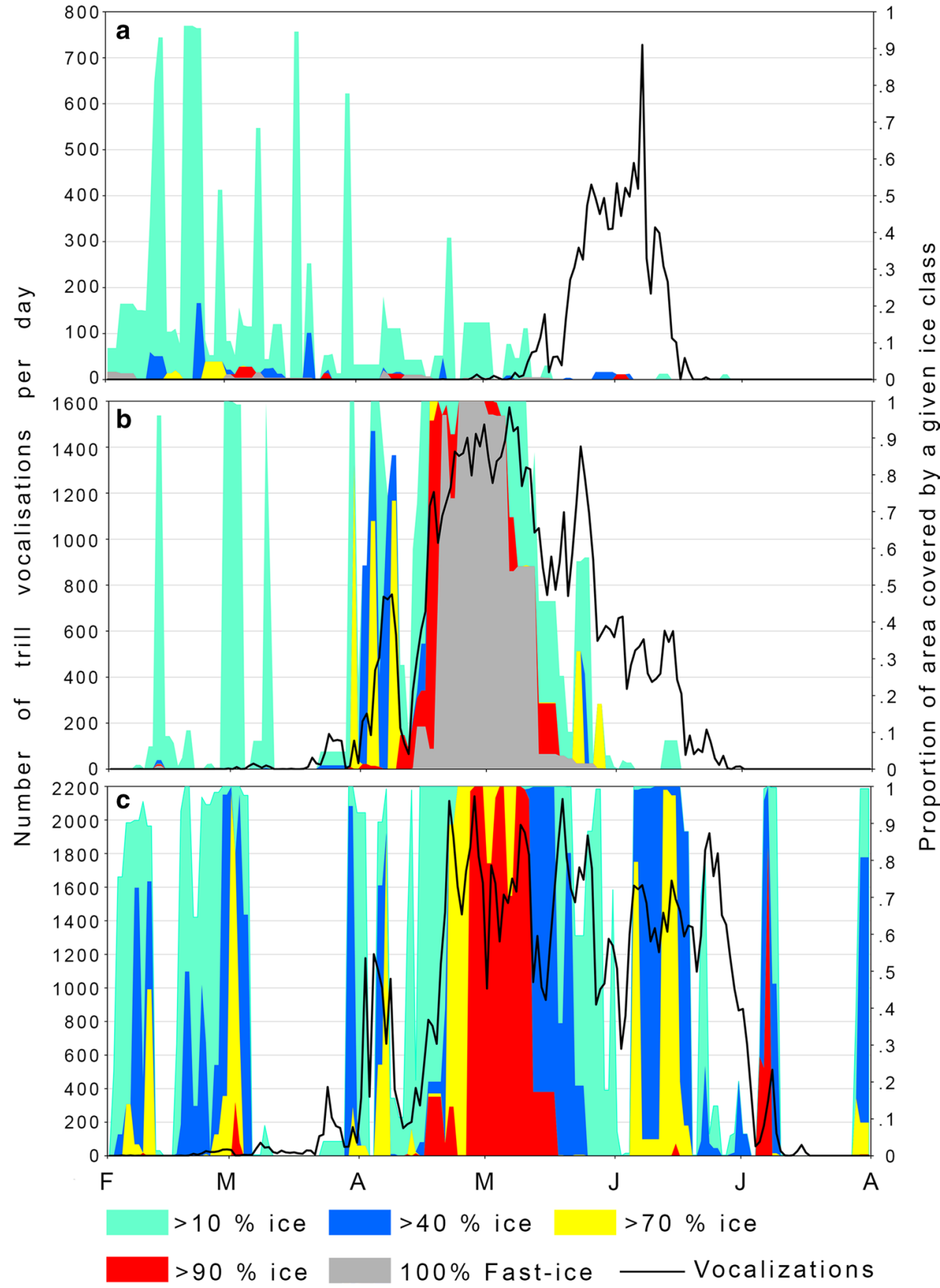

the long period of trill activity reflects asynchronous birthing, and hence mating, in this area or sequential influxes of females to the area over a longer period than in the fjord sites.

Trill rates showed a distinct peak in Rijpfjorden, starting in late-April and culminating during the first week of May, with more than 300 trills per h. This early spring singing and the following decline in vocal rates at this High Arctic site was somewhat surprising, particularly given the heavy ice cover usually present in April in fjords in north-eastern Svalbard (Wallace et al. 2010). The time span of trill vocalizations at Rijpfjorden encompassed May-June, which was the time frame that was the norm for pupping and nursing in Kongsfjorden in the past (Kovacs et al. 2020), though seasonality of these activities has never been specifically documented at Rijpfjorden. The peak in trill vocal activity in Kongsfjorden occurred at the end of May-beginning of June in the present study. This is similar to what has been reported previously for this area (Van Parijs et al. 2001; de Vincenzi et al. 2019). The trill rates found in Kongsfjorden during the peak of the season were similar to those documented at the outer fjord site in de Vincenzi et al. (2019). Although it is 
challenging to compare calling rates across different studies because of inclusion of different numbers of call types, it appears that the calling rate has declined in Kongsfjorden over the last few decades. Van Parijs et al. (2001) reported an average of 100 vocalizations per $10 \mathrm{~min}$, while the current study documents approximately 80 vocalizations per $h$.

Few studies address the functional traits of the vocal repertoire of bearded seals. In this study, the seasonal use of different types of trills was explored to attempt to gain insight into what call types might be most important in a mating context in varied ice environments. By increasing the duration and redundancy in their calling behaviour, bearded seal males likely increase the probability of reaching oestrus females and other males with their signals, despite their dispersed distribution in various types of sea ice environments, where signal to noise ratios tend to be low (Urick and Kuperman 1989; Geyer et al. 2016). The long trill, which has been reported to be the most commonly used call type during the mating season in Svalbard, has a longer duration compared to step and sweep trills, especially in the low-frequency range, contributing to a better propagation of sound underwater (Van Parijs et al. 2001; Risch et al. 2007). It also starts at higher frequencies with a sudden drop of frequency early in the vocalization and it has more pronounced steps in the low-frequency range. These properties are thought to contribute to reducing masking in environments where sea ice cover is the norm (Cleator et al. 1989; Terhune 1999; Hildebrand 2009).

Differential use of trill call types was exhibited on a seasonal basis at two of the three sites in this study. At Atwain, the long trill was by far the most commonly used trill type followed by step trill. This site had much more extensive ice cover on average compared to the other two locations. The high use of the long trill likely reflects an attempt by males to signal to a dispersed audience of females whose distribution is unpredictable in the noisy drift-ice environment. Nursing females are likely transient, shifting location with the moving pack-ice. If the ice used by a mother-pup pair drifts off the shelf into deep water, the female would likely swim with her pup back to shallow areas where she can feed. Such movements have been documented in the Kongsfjorden area (Hammill et al. 1994). In that situation, high long trill rates over long periods and a roaming strategy by singing males would likely become advantageous. In similar drift-ice environments at the edge of the Chukchi Sea and Beaufort Sea, longer trill types increased towards the peak of the mating season (Frouin-Mouy et al. 2016). Segregation in call type use was also found in Rijpfjorden, but to a lesser degree than at Atwain. The ice is more stable in Rijpfjorden, with land-fast sea ice covering the fjord during much of the spring and early summer, providing a quieter acoustic habitat (Diachok and Winokur, 1974), although drift-ice is sometimes advected into the outer part of Rijpfjorden as it is in Kongsfjorden (pers obs KMK \& CL). The distribution of breeding females is likely more predictable in Rijpfjorden than in Atwain. The segregation in call rates was moderate in Rijpfjorden. Sweep trills, with their greater frequency range but shorter durations, were used as much as were long trills, while the area had land-fast-ice. However, long trills became the most abundant call type after the break-up of the fast-ice platform began in Rijpfjorden, when the overall trill rates were highest and the ice environment was most dynamic. However, this change occurred concomitantly with moving towards what is likely peak breeding time for bearded seals in this area. There was no seasonal segregation of call use in Kongsfjorden. Van Parijs et al. (2001) found a constant higher proportion of long trills during the breeding period in Kongsfjorden than in the present study, when ice conditions were more extensive. The low number of long trills recorded in Kongsfjorden suggests that little breeding is now taking place in this fjord.

Some studies have addressed the effect of environmental factors on the evolution of mating systems in pinnipeds, in which vocal behaviour plays an important role for many species (Rogers 2003; Stirling and Thomas 2003; Davis et al. 2008). A positive relationship between ice cover and bearded seal vocal displays has been reported in many previous studies (e.g. MacIntyre et al. 2015; Frouin-Mouy et al. 2016; Jimbo et al. 2019). Atwain had the most extensive ice conditions of the three study sites. However, trill vocal activity at Atwain was not correlated directly with sea ice concentrations; high vocal activity occurred with ice concentrations from near zero to over $90 \%$. At Rijpfjorden, trill vocalizations were tightly coupled to the period with the heaviest ice cover in this location. In Kongsfjorden, trill vocalizations started in the beginning of May, shortly after the ice disappeared in this area. The lack of trill vocalizations detected in this study prior to May suggests that males focus their singing towards the end of the pup rearing period, when they can maximize breeding potential. de Vincenzi et al. (2019) suggested that males move from the glacier fronts, where feeding activity and rest dominate their behavioural activity budgets (Hamilton et al. 2018), to traditional display territories further out in the fjord in May, where they might intercept females using the bottleneck entrance to the fjord (Van Parijs et al. 2001). However, this timing now represents a mismatch with the time during which sea ice is available in this fjord. These sorts of phenological mismatches are a major concern with respect to the potential impacts of climate change on Arctic fauna (Kovacs et al. 2011).

High site fidelity might limit male's flexibility in responding to changes in environmental conditions, although previous studies suggested that plastic responses in mating tactics by this species are possible (Van Parijs and Clark 2006; Frouin-Mouy et al. 2016). Some of the differences in trill type use observed by location might reflect the selection 
of different strategies dependent on the age, size or experience of males. Unfortunately, there are no data available to test this speculation. Additionally, differences in propagation of sound and sound reception might exist among locations, but no consistent site-specific patterns were observed throughout the season, and high vocal rates occurred both at a fjord location and at the drift-ice site. The consequences of climate change and its impacts on bearded seals are difficult to predict. Bearded seals in Kongsfjorden adapted to the first major ice declines in the mid-2000s by exploiting ice calved from glaciers in areas where tidewater glaciers meet the sea, for birthing, nursing their young and resting (Lydersen et al. 2014, Kovacs et al. 2020), though the results of the current study suggest reduced vocal activity compared to 20 years ago in this area (Van Parijs et al. 2001). Vocal rates are currently much higher in Rijpfjorden compared to Kongsfjorden. However, as temperatures increase in the coming decades, the hydrographic regime, sea ice cover and community composition in Rijpfjorden are expected to undergo changes similar to what has already taken place in Kongsfjorden (Wallace et al. 2010; Onarheim et al. 2014; Hop et al. 2019; Weydmann-Zwolicka et al. 2021). Heat advection from Atlantic Water is also expected to increase in the future, which will continue to drive sea ice losses and the displacement of the pack-ice towards the north, beyond the shelf and into the deep Arctic Ocean Basin (Polyakov et al. 2017). This would affect the breeding ecology of bearded seals at Atwain.

Female bearded seals feed during lactation, so ideal breeding environments have ice for birthing and nursing pups, located over shallow water where females can easily reach benthic food resources (Krafft et al. 2000; Kovacs 2018). As the ice recedes northward, increased primary production is expected over the Arctic shelves (Randelhoff and Sundfjord 2018). However, increased primary production will not necessarily benefit bearded seals if there are no ice platforms for breeding in areas where females can feed during the pupping period (Kovacs et al. 2011; MacIntyre et al. 2015). Both adults and large juvenile bearded seals have been observed hauled out on land in Svalbard in recent years in Svalbard (e.g. Merkel et al. 2013). However, mother-pup pairs have never been seen using land; such a shift would represent a major change in the breeding behaviour of this species and would not likely be a successful strategy in places, such as Svalbard, where polar bear (Ursus maritimus) predation rates would be expected to be very high. Reductions in benthic community production due to reduced sympagic fall-out is also a concern for bearded seals (Cameron et al. 2010). The further retreat of ice and related alterations to the breeding and resting habitats of bearded seals pose a threat to this species. The US government has already listed the Beringia DPS bearded seals population (segment) as "threatened" under the ESA (77 FR 76740) on this basis. Similarly, the Norwegian Government's new Red List recognizes bearded seals as Near Threatened on the basis of climate change impacts on their habitat (https:// rl2021.artsdatabanken.no).

The results of this study show that bearded seals vocalize for a longer period than previously thought in Svalbard and that trill rates at a newly studied drift-ice site were considerably higher than anticipated. A reduction in trill rates has occurred in Kongsfjorden, suggesting a reduction in the number of bearded seals in this area, which has been subjected to Atlantification over the last 1.5 decades. Segregation in the use of trill types at the two most active locations suggests somewhat different functionality of these calls, or perhaps different transmission characteristics that can be used within different noise environments or with varying levels of competition pressure. There was clearly preferential use of long trills in the drift-ice location, where the challenging sound environment, and perhaps also the variable and unpredictable locations of females, might lead to high competition between males. Future studies should explore PAM data over longer periods (multiple years of data) and preferably include all call types. Ideally, surveys or direct observational studies should be conducted concomitantly with PAM to enhance our understanding of the behaviour of this little-known species and to calibrate acoustic monitoring as a tool for assessing abundance. Knowledge of relative densities and age structures (particularly of males), in combination with vocal studies, would allow us to reduce the speculative nature of behavioural interpretations. Studies using underwater observation technologies (set-site camera at known display sites or mobile robotics) would be required to confirm behaviours associated with specific call types. Although such studies are theoretically possible, considerable logistic investment would be required to undertake them.

Acknowledgements The authors thank Kristen Fossan (NP) for servicing the Atwain AURAL and Arild Sundfjord for running the Atwain research programme. Daniel Vogedes (Uit) and Rupert Krapp (NP) prepared and deployed the Kongsfjorden and Rijpfjorden AURALs. Jade Vacquié-García provided advice with model design and the ice sampling methodology, and Oddveig Øien Ørvoll for the drafting the maps. Michael Cameron and Marianne Marcoux provided valuable suggestions regarding revision of the manuscript.

Author contributions KMK and CL established the PAM network in Svalbard. KMK, HA and CL conceived and designed the research project. JB ensured infrastructure support for deploying and recovering the Kongsfjorden and Rijpfjorden moorings. HA and SML extracted the bearded seals data sets and set up the analytical frameworks. SML analysed the data and drafted the manuscript. RI provided statistical guidance. All the authors provided editorial inputs and approved the manuscript.

Funding Open access funding provided by Norwegian Polar Institute. This work was funded by the Fram Centre MIKON programme, the Svalbard Environmental Protection Fund, the Svalbard Science Forum, the Fram Centre Incentive Fund, the Norwegian Research 
Council ARK Project No. 313676, the EU FACE-IT programme (Project No. 8691549) and the Norwegian Polar Institute. Data collection at ATWAIN was supported by the Sea ice in the Arctic Ocean, technology and governance, Fram Centre Flagship Programme (Project No. 66050).

\section{Declarations}

Conflict of interest No potential conflict of interest was reported by the authors.

Open Access This article is licensed under a Creative Commons Attribution 4.0 International License, which permits use, sharing, adaptation, distribution and reproduction in any medium or format, as long as you give appropriate credit to the original author(s) and the source, provide a link to the Creative Commons licence, and indicate if changes were made. The images or other third party material in this article are included in the article's Creative Commons licence, unless indicated otherwise in a credit line to the material. If material is not included in the article's Creative Commons licence and your intended use is not permitted by statutory regulation or exceeds the permitted use, you will need to obtain permission directly from the copyright holder. To view a copy of this licence, visit http://creativecommons.org/licenses/by/4.0/.

\section{References}

Ahonen H, Kathleen MS, Lydersen C, Steur L, Kovacs KM (2019) A multi-year study of narwhal occurrence in the western Fram Strait-detected via passive acoustic monitoring. Polar Res 38:1-14

Bivand RS, Pebesma E, Gómez-Rubio V (2013) Applied spatial data analysis with R, 2nd edn. Springer, New York

Blanchet M-A, Lydersen C, Ims RA, Kovacs KM (2015) Seasonal, oceanographic and atmospheric drivers of diving behaviour in a temperate seal species living in the high Arctic. PLoS ONE 10:e0132686. https://doi.org/10.1371/journal.pone.0132686

Burns JJ (1981) Bearded seal, Erignathus barbatus. In: Ridgway SH, Harrison RJ (eds) Handbook of marine mammals, vol 2. Seals. Academic Press, London, pp 145-170

Cameron MF, Bengtson JL, Boveng PL, Jansen JK, Kelly BP, Dahle SP, Logerwell EA, Overland JE, Sbrine CL, Waring GT, Ilser JM (2010). Status review of the bearded seal (Erignathus barbatus). NOAA Technical Memorandum NMFS-AFSC-211

Cameron M, Frost KJ, Ver Hoef JM, Breed GA, Whiting AV, Goodwin J, Boveng PL (2018) Habitat selection and seasonal movements of young bearded seals (Erignathus barbatus) in the Bering Sea. PLoS ONE 13:e0192743. https://doi.org/10.1371/journal.pone. 0192743

Charlton BD, Reby D (2016) The evolution of acoustic size exaggeration in terrestrial mammals. Nat Commun 7:12793. https://doi. org/10.1038/ncomms12739

Cleator H, Stirling I, Smith T (1989) Underwater vocalizations of the bearded seal (Erignathus barbatus). Can J Zool 67:1900-1910. https://doi.org/10.1139/z89-272

Cottier FR, Nilsen F, Inall ME, Gerland S, Tverberg V, Svendsen H (2007) Wintertime warming of an Arctic shelf in response to large-scale atmospheric circulation. Geophys Res Lett 34:L10607. https://doi.org/10.1029/2007GL029948

Davis CS, Stirling I, Strobeck C, Coltman DW (2008) Population structure of ice-breeding seals. Mol Ecol 17:3078-3094. https://doi. org/10.1111/j.1365-294X.2008.03819.x de Vincenzi G, Parisi I, Torri M, Papale E, Mazzola S, Nuth C, Buscaino $G$ (2019) Influence of environmental parameters on the use and spatiotemporal distribution of the vocalizations of bearded seals (Erignathus barbatus) in Kongsfjorden, Spitsbergen. Polar Biol 42:1241-1254. https://doi.org/10.1007/s00300-019-02514-3

Diachok OI, Winokur RS (1974) Spatial variability of underwater ambient noise at the Arctic ice-water boundary. J Acoust Soc Am 55:750. https://doi.org/10.1121/1.1914594

Frouin-Mouy H, Mouy X, Martin B, Hannay D (2016) Underwater acoustic behavior of bearded seals (Erignathus barbatus) in the northeastern Chukchi Sea, 2007-2010. Mar Mamm Sci 32:141160. https://doi.org/10.1111/mms.12246

Geyer F, Sagen H, Hope G, Babiker M, Worcester PF (2016) Identification and quantification of soundscape components in the Marginal Ice Zone. J Acoust Soc Am 139:1873-1885. https://doi.org/10. $1121 / 1.4945989$

Hamilton CD, Kovacs KM, Lydersen C (2018) Individual variability in diving, movement and activity patterns of adult bearded seals in Svalbard, Norway. Sci Rep 8:16988. https://doi.org/10.1038/ s41598-018-35306-6

Hammill MO, Kovacs KM, Lydersen C (1994) Local movements by nursing bearded seal (Erignathus barbatus) pups in Kongsfjorden, Svalbard. Polar Biol 14:569-570. https://doi.org/10.1007/BF002 38227

Hildebrand JA (2009) Anthropogenic and natural sources of ambient noise in the ocean. Mar Ecol Prog Ser 395:5-20. https://doi.org/ $10.3354 /$ meps 08353

Hjelset AM, Andersen M, Gjertz I, Lydersen C, Gulliksen B (1999) Feeding habits of bearded seals (Erignathus barbatus) from the Svalbard area, Norway. Polar Biol 21:186-193. https://doi.org/ $10.1007 / \mathrm{s} 003000050351$

Hop H, Assmy P, Wold A, Sundford A, Daase M, Duarte P, Kwasniewski S, Gluchowska M, Wiktor JM, Tatarek A, Wiktor JJ, Kristiansen S, Fransson A, Melissa C, Vihtakari M (2019) Pelagic ecosystem characteristics across the Atlantic water boundary current from Rijpfjorden, Svalbard, to the Arctic Ocean during summer (2010-2014). Front Mar Sci 6:181. https://doi.org/10. 3389/fmars.2019.00181

Jimbo M, Mizuguchi D, Shirakawa H, Tsujii K, Fijiwara A, Miyashita K, Mitani Y (2019) Seasonal variations in the call presence of bearded seals in relation to sea ice in the southern Chukchi Sea. Polar Biol 42:1953-1958. https://doi.org/10.1007/ s00300-019-02569-2

Kovacs KM (2018) Bearded seal: Erignathus barbatus. In: Würsig B, Thewissen JGM, Kovacs KM (eds) Encyclopedia of marine mammals, 3rd edn. Academic Press, London, pp 83-86

Kovacs KM, Lydersen C (2008) Climate change impacts on seals and whales in the North Atlantic Arctic and adjacent shelf seas. Sci Prog 91:117-150. https://doi.org/10.3184/003685008X324010

Kovacs KM, Lydersen C, Gjertz I (1996) Birth-site characteristics and prenatal molting in bearded seals (Erignathus barbatus). J Mammal 77:1085-1091. https://doi.org/10.2307/1382789

Kovacs KM, Lydersen C, Overland J, Moore SE (2011) Impacts of changing sea-ice conditions on Arctic marine mammals. Mar Biodiv 41:181-194. https://doi.org/10.1007/s12526-010-0061-0

Kovacs KM, Krafft BA, Lydersen C (2020) Bearded seal (Erignathus barbatus) birth mass and pup growth in periods with contrasting ice conditions in Svalbard, Norway. Mar Mamm Sci 2019:1-9

Krafft BA, Lydersen C, Kovacs KM, Gjertz I, Haug T (2000) Diving behaviour of lactating bearded seals (Erignathus barbatus) in the Svalbard area. Can J Zool 78:1408-1418. https://doi.org/ $10.1139 / \mathrm{z} 00-088$

Laidre KL, Stern H, Kovacs KM, Lowry L, Moore SE, Regehr EV, Ferguson SH, Wigg Ø, Boveng P, Angliss RP, Born EW, Litovka D, Quakenbush L, Lydersen C, Vongraven D, Ugarte F (2015) Arctic marine mammal population status, sea ice habitat loss, and 
conservation recommendations for the 21st century. Conserv Biol 29:724-737. https://doi.org/10.1111/cobi.12474

Lydersen C, Kovacs KM (1999) Behaviour and energetics of ice-breeding, North Atlantic phocid seals during the lactation period. Mar Ecol Prog Ser 187:265-281. https://doi.org/10.3354/meps187265

Lydersen C, Hammill MO, Kovacs KM (1994) Diving activity in nursing bearded seal (Erignathus barbatus) pups. Can J Zool 72:96103. https://doi.org/10.1139/z94-013

Lydersen C, Assmy P, Falk-Petersen S, Kohler J, Kovacs KM, Reigstad M, Steen H, Strøm H, Sundfjord A, Varpe $\varnothing$, Walczowski W, Weslawski JM, Zajaczkowski M (2014) The importance of tidewater glaciers for marine mammals and seabirds in Svalbard, Norway. J Mar Syst 129:452-471. https://doi.org/10.1016/j.jmarsys. 2013.09.006

MacIntyre KQ, Stafford KM, Berchok CL, Boveng PL (2013) Yearround acoustic detection of bearded seals (Erignathus barbatus) in the Beaufort Sea relative to changing environmental conditions, 2008-2010. Polar Biol 36:1161-1173. https://doi.org/10. 1007/s00300-013-1337-1

MacIntyre KQ, Stafford KM, Conn PB, Laidre KL, Boveng PL (2015) The relationship between sea ice concentration and the spatiotemporal distribution of vocalizing bearded seals (Erignathus barbatus) in the Bering, Chukchi, and Beaufort Seas from 2008 to 2011. Prog Oceanogr 136:241-249. https://doi.org/10.1016/j. pocean.2015.05.008

Merkel B, Lydersen C, Yoccoz NG, Kovacs KM (2013) The world's northernmost harbour seal population-how many are there? PLoS ONE 8:e67576. https://doi.org/10.1371/journal.pone.0067576

Moore SE, Huntington HP (2008) Arctic marine mammals and climate change: impacts and resilience. Eccol Appl 18:S157-S165. https:// doi.org/10.1890/06-0571.1

Moore SE, Reeves RR, Southall BL, Ragen TJ, Suydam RS, Clark CW (2012) A new framework for assessing the effects of anthropogenic sound on marine mammals in a rapidly changing Arctic. Bioscience 62:289-295. https://doi.org/10.1525/bio.2012.62.3.10

Onarheim IH, Smedsrud LH, Ingvaldsen RB, Nilsen F (2014) Loss of sea ice during winter north of Svalbard. Tellus A 66:23933. https://doi.org/10.3402/tellusa.v66.23933

Owings DH, Morton ES (1998) Animal vocal communication: a new approach. Cambridge University Press, Cambridge

Parisi I, de Vincenzi G, Torri M, Papale E, Mazzola S, Bonanno A, Buscaino G (2017) Underwater vocal complexity of Arctic seal Erignathus barbatus in Kongsfjorden (Svalbard). J Acoust Soc Am 142:3104-3115. https://doi.org/10.1121/1.5010887

Polyakov IV, Pnyushkov AV, Alkire MB, Ashik IM, Baumann TM, Carmack EC, Goszczko I, Guthrie J, Ivanov VV, Kanzow T, Krishfield R, Kwok R, Sundfjord A, Morison J, Rember R, Yulin A (2017) Greater role for Atlantic inflows on sea-ice loss in the Eurasian Basin of the Arctic Ocean. Science 356:285-291. https:// doi.org/10.1126/science.aai8204

Randelhoff A, Sundfjord A (2018) Short commentary on marine productivity at Arctic shelf breaks: upwelling, advection and vertical mixing. Ocean Sci 14:293-300. https://doi.org/10.5194/ os-14-293-2018

Reeves RR, Ewins PJ, Agbayani S, Heide-Jørgensen MP, Kovacs KM, Lydersen C, Suydam R, Elliott W, Polet G, van Dijk Y, Blijleven R (2014) Distribution of endemic cetaceans in relation to hydrocarbon development and commercial shipping in a warming Arctic. Mar Policy 44:375-389. https://doi.org/10.1016/j.marpol.2013. 10.005

Renner AHH, Sundfjord A, Janout MA, Ingvaldsen RB, BeszczynskaMöller A, Pickart RS, Pérez-Hernández MD (2018) Variability and redistribution of heat in the Atlantic water boundary current north of Svalbard. J Geophys Res-Oceans 123:6373-6391. https:// doi.org/10.1029/2018JC013814
Risch D, Clark CW, Corkeron PJ, Elepfandt A, Kovacs KM, Lydersen C, Stirling I, Van Parijs SM (2007) Vocalizations of male bearded seals, Erignathus barbatus: classification and geographical variation. Anim Behav 73:747-762. https://doi.org/10.1016/j.anbeh av.2006.06.012

Rogers T (2003) Factors influencing the acoustic behaviour of male phocid seals. Aquat Mamm 29:247-260. https://doi.org/10.1578/ 016754203101024185

Stafford KM, Laidre KL, Heide-Jørgensen MP (2012) First acoustic recordings of narwhals (Monodon monoceros) in winter. Mar Mamm Sci 28:E197-E207. https://doi.org/10.1111/j.1748-7692. 2011.00500.x

Stirling I, Thomas J (2003) Relationships between underwater vocalizations and mating systems in phocid seals. Aquat Mamm 29:227246. https://doi.org/10.1578/016754203101024176

Taylor AM, Reby D (2010) The contribution of source-filter theory to mammal vocal communication research. J Zool 280:221-236. https://doi.org/10.1111/j.1469-7998.2009.00661.x

Terhune JM (1999) Pitch separation as a possible jamming-avoidance mechanism in underwater calls of bearded seals (Erignathus barbatus). Can J Zool 77:1025-1034. https://doi.org/10.1139/z99-067

Tverberg V, Skogseth R, Cottier F, Sundfjord A, Walczowski W, Inall ME, Falck E, Pavlova O, Nilsen F (2019) The Kongsfjorden transect: seasonal and inter-annual variability in hydrography. In: Hop $\mathrm{H}$, Wiencke C (eds) The ecosystem of Kongsfjorden, Svalbard. Springer, Cham, pp 49-104

Tweedie MCK (1984) An index which distinguishes between some important exponential families. In: Ghosh JK, Roy J (eds) Statistics: Applications and New Directions. Proceedings of the Indian Statistical Institute Golden Jubilee International Conference. Indian Statistical Institute, Calcutta, pp 579-604

Urbanski JA, Litwicka D (2021) Accelerated decline of Svalbard coasts fast ice as a result of climate change. Cryosphere. https://doi.org/ 10.5194/tc-2021-21

Urick R, Kuperman WA (1989) Ambient Noise in the Sea. J Acoust Soc Am 86:1626. https://doi.org/10.1121/1.398683

Van Parijs SM, Clark CW (2006) Long-term mating tactics in an aquatic-mating pinniped, the bearded seal, Erignathus barbatus. Anim Behav 72:1269-1277. https://doi.org/10.1016/j.anbehav. 2006.03.026

Van Parijs SM, Kovacs KM, Lydersen C (2001) Spatial and temporal distribution of vocalising male bearded seals - Implications for male mating strategies. Behaviour 138:905-922. https://doi.org/ $10.1163 / 156853901753172719$

Van Parijs SM, Lydersen C, Kovacs KM (2003) Vocalizations and movements suggest alternative mating tactics in male bearded seals. Anim Behav 65:273-283. https://doi.org/10.1006/anbe. 2003.2048

Van Parijs SM, Lydersen C, Kovacs KM (2004) Effects of ice cover on the behavioural patterns of aquatic-mating male bearded seals. Anim Behav 68:89-96. https://doi.org/10.1016/j.anbehav.2003. 09.013

Wallace MI, Cottier FR, Berge J, Tarling GA, Griffiths C, Brierley AS (2010) Comparison of zooplankton vertical migration in an ice-free and a seasonally ice-covered Arctic fjord: an insight into the influence of sea ice cover on zooplankton behavior. Limnol Oceanogr 55:831-845. https://doi.org/10.4319/lo.2010.55.2.0831

Wassmann P, Kosobokova KN, Slagstad D, Drinkwater KF, Hopcroft RR, Moore SE, Ellingsen I, Nelson RJ, Carmack E, Popova E, Berge J (2015) The contiguous domains of Arctic Ocean advection: trails of life and death. Prog Oceanogr 139:42-65. https:// doi.org/10.1016/j.pocean.2015.06.011

Weydmann-Zwolicka A, Pratnicka P, Lacka M, Majaneva S, Cottier F, Berge J (2021) (2021) Zooplankton and sediment influxes in two contrasting fjords reveal Atlantification of the Arctic. Sci Total 
Environ 773:145599. https://doi.org/10.1016/j.scitotenv.2021. 145599

Wood SN, Pya N, Säfken B (2016) Smoothing parameter and model selection for general smooth models. J Am Stat Assoc 111:15481563. https://doi.org/10.1080/01621459.2016.1180986
Publisher's Note Springer Nature remains neutral with regard to jurisdictional claims in published maps and institutional affiliations. 